\title{
Effect of methotrexate and vitamin A on NOR expression in seminiferous tubules of Wistar rats
}

\author{
REGHUNATHAN, D. ${ }^{1}$, BHAT, K. R. ${ }^{2}$, BAIRY, K. L. ${ }^{3}$, MURLIMANJU, \\ B. V. ${ }^{* 4}$ and PRASAD, A. M. ${ }^{1}$
}

\author{
${ }^{1}$ Department of Anatomy, Melaka Manipal Medical College, Manipal Campus, Manipal University, Manipal, India \\ ${ }^{2}$ Department of Anatomy, Kasturba Medical College, Manipal University, Manipal, India \\ ${ }^{3}$ Department of Pharmacology, Kasturba Medical College, Manipal University, Manipal, India \\ ${ }^{4}$ Assistant Professor of Anatomy, Department of Anatomy, Kasturba Medical College, \\ Manipal University, Bejai, Mangalore, India \\ *E-mail: flutemist@gmail.com
}

\begin{abstract}
Introduction: The histopathology and expression of nucleolar organizing regions (NORs), of seminiferous tubules was studied after the administration of methotrexate (MTX) and vitamin A (VA). Objective of the study was to test if the NOR count increases or decreases with different doses of MTX. Material and Methods: Male Wistar rats aged 4 months, maintained in our institution were used in the present study. The rats were divided into following groups, group I - control (saline treated), group II - animals treated with 8 mg of MTX, group III - animals treated with $10 \mathrm{mg}$ of MTX, group IV - animals treated with $12 \mathrm{mg}$ of MTX, group V - animals treated with VA (5000 IU), Group VI - animals treated with VA (5000 IU) and MTX (12 mg). Results: The animals treated with MTX showed significant decrease in the diameter of seminiferous tubules and increase in interstitial space. The spermatogenesis was not complete in some tubules. When MTX was given with VA, the damage done by MTX was decreased. There was an overall numerical decrease in the total NOR count from the control to $12 \mathrm{mg}$ dose MTX. The total count included small, medium and large sized NORs. Conclusion: Higher the dose of MTX, lesser the NOR count and lesser the irregularity of NORs. However VA co-administration reduces the damage produced by MTX. We believe that findings of the present study might be useful in understanding the long term effect of MTX and its adverse effects.
\end{abstract}

Keywords: methotrexate, NOR, AgNOR, histopathology, vitamin A.

\section{Introduction}

Nucleolar organizing regions (NORs) are the loops of ribosomal DNA present in the nucleus of cells (FAWCETT, 1994). NORs are sometimes called Argyrophylic nucleolar organizer regions (AgNORs) because of their strong affinity towards silver (PLOTON, MENAGER, JEANNESSON et al., 1986; FAKAN and HERNANDEZVERDUN, 1986).AgNORstaining is a simple and economical technique for investigating the proliferative activity. NORs vary in size and shape according to the nucleolar transcription and are related to the degree of maturity of cells (MAMAEV, MAMAEVA, LIBURKINA et al., 1985), the cell cycle and proliferative activity in some circumstances (DERENZINI, PESSION, FARABEGOLI et al., 1989; LEEK, SARRAF and ALISION, 1990; SURESH, CHAWNER, BUCKLEY et al., 1990). Silver staining has been useful not only for studying the structure of nucleolus but also its variations in the pathological situations (HOWELL, 1982). The literature on AgNORs suggests that there may be a possible association between AgNOR count and disease transformation. It is well known that methotrexate (MTX) is one of the commonest drugs used to treat several diseases. MTX formerly known as amethopterin, is an antifolate and antimetabolite drug which acts by inhibiting folate metabolism by its effect on dihydrofolate reductase. Since the effect of MTX is not selective for the cancer cells, it also affects normal tissues, which have high rate of proliferation, including the actively dividing cells of genitalia. The MTX is well known for its teratogenic effects in humans. The literature review on MTX reveals few interesting facts. No toxicity was observed in the intratunical injection of MTX, which was used for the treatment of bilateral testicular seminoma. However, a temporary drop of sperm count occurred during the treatment (SHAFIK, 1993). The possible deleterious effects of folic acid as antagonist to MTX on the fertility potential in psoriatic patients revealed that MTX had no unfavorable effect on male fertility (EL-BEHEIRY, EL-MANSY, KAMEL et al., 1979).

It was also reported that administration of vitamin A (VA) decreases the MTX induced damage to the testicular cells. This protective effect of VA may have clinical applications in cancer chemotherapy (YUNCU, ERALP, KORUK et al., 2004). Administration of VA before the high dose MTX might protect against drug induced D-xylose malabsorption in children with cancer (DAGDEMIR, YILDIRIM, ALIYAZICIOGLU et al., 2004). In the present study, the histopathology and expression of NORs of Wistar rat seminiferous tubules was studied after the administration of MTX and MTX+VA. It is interesting to hypothesize the number, shape, and the distribution of AgNORs after the administration of MTX. VA was used to check if any improvement in the MTX induced damage to the seminiferous tubules and the NOR quantity. Objective of the study was to test if the AgNOR count increases or decreases with different doses of MTX. 


\section{Materials and Methods}

\subsection{Animals}

Male Wistar rats with an average weight of $200 \mathrm{~g}$ and aged about 4 months were used in the present study. The rats were maintained in an air-conditioned animal house under controlled conditions of light, temperature and humidity. The Manipal University Ethical Committee has approved the present study.

\subsection{Chemicals}

MTX was obtained from NEON antibiotics Pvt Ltd., Thane, India. VA was obtained from USV Ltd., Mumbai, India. Thiomersal IP $0.01 \% \mathrm{w} / \mathrm{v}$ was used as preservative in the present study. AgNO3 was obtained from NICE Chemicals Pvt. Ltd., Cochin, India. Gelatin was obtained from S. D Fine Chemicals Pvt. Ltd., Mumbai, India.

\subsection{Design of experiment}

A total of 36 male Wistar rats were divided into six groups. Group I served as control and received saline. Group II, III and IV received MTX 8,10 and $12 \mathrm{mg} / \mathrm{kg}$ respectively. Group V received VA 5000 IU and group VI received VA $5000 \mathrm{IU}$ and MTX $12 \mathrm{mg} / \mathrm{kg}$.

\subsection{MTX and VA administration}

Animals were injected intraperitoneally with different doses $(8 \mathrm{mg}, 10 \mathrm{mg}, 12 \mathrm{mg}$ ) of MTX on alternative days for one week and sacrificed on the seventh day by using the ether. Animals injected with VA (5000 U) and MTX along with VA (12mg and $5000 \mathrm{IU})$ were also sacrificed on the seventh day.

\subsection{Tissue processing}

After sacrificing the animals, the testes were removed and kept in $10 \%$ formalin for 48 hrs (post fixation). Paraffin blocks were made in an embedding bath. Sections of 3-5 micron thickness were cut from the blocks using rotary microtome. The sections were mounted on air dried gelatinized slides and stained with haematoxylin and eosin. Testicular histopathology was evaluated with high power (40X) field.

\subsection{NOR study}

\subsubsection{Preparation of AgNO3 solution}

To prepare $50 \%$ of silver nitrate solution, $5 \mathrm{gm}$ of silver nitrate powder was dissolved in $10 \mathrm{ml}$ of distilled water and filtered through Whatman filter paper in a dark room. The solution was stored in a dark bottle at $40{ }^{\circ} \mathrm{C}$, and used within one week.

\subsubsection{Preparation of gelatin}

One gram of powdered gelatin was dissolved in $49 \mathrm{ml}$ of distilled water and $1 \mathrm{ml}$ of formic acid. To dissolve faster, the mixture was kept in hot water bath at $60{ }^{\circ} \mathrm{C}$ for at least 10 minutes. The solution was stored in a dark bottle at $40{ }^{\circ} \mathrm{C}$ and used within one week.

\subsubsection{Silver nitrate staining}

Rapid staining and de-staining method developed by Dhar, Kumar, Nayak et al. (1995) was used in the present study.

\subsubsection{Microscopic observation}

Standard protocols were followed for recording the number and quantitation of the size and shape of AgNOR dots (CROCKER, BOLDY and EGAN, 1989).

\subsection{NOR count}

Areas with minimal cell overlap and no artifact were demarcated for counting. Weak or dark stained slides were not evaluated. The NORs appeared as black dots within the orange colored nuclear background. The dots were defined as discrete homogenous silver precipitates with well-defined edges. Overlapped dots with well-defined edges were counted as greater than one when appeared while viewing through different focal planes. Dots lying in a group with indistinguishable boundaries were treated as one dot. Dots outside the nucleolus were not considered. Observations were completed within one week of staining; since the stain will fade on prolonged storage. The counting was done using oil immersion at 400X field.

\subsection{NOR size}

The size of NOR was measured using ocular micrometer (calibrated with stage micrometer). The groups were classified into three groups based on their diameter (small $\leq 1 \mu \mathrm{m}$, medium between $>1$ and $\leq 3 \mu \mathrm{m}$ and large $>3 \mu \mathrm{m}$ ).

\subsection{NOR shape}

Based on shape, NORs were classified into regular (with round or oval well-defined margin) and irregular (with serrated margin). In each category, the size of all dots was documented.

\subsection{Statistical analysis}

The mean NOR count data; size wise distribution of dots were tested by using one way ANOVA. Since the test of homogeneity of variance showed significance between different groups, data were reanalyzed using square root transformation. For each dose and distribution, mean NOR count, standard deviation, f-ratio and p-value were computed.

\section{Results}

The histopathological study of effect of MTX as well as the dose wise expression of NORs in the testis was considered as the parameters in the present investigation. The data was collected and analyzed based on the following parameters.

\subsection{Histopathology (Figure 1)}

The samples after administering MTX, showed significant decrease in the diameter of seminiferous tubules (Figure 1B), followed by increase in interstitial space when compared to the control sample (Figure 1A). The size of various stages of primary, secondary spermatocytes and spermatids was altered significantly compared to the controls. Vacuolization/ decondensation of "chromatin-mass" in spermatocytes changed from round to oval. The size of the Sertoli and Leydig cells was reduced significantly. The basement membrane at some places seemed to be disrupted and thin. MTX induced cytotoxicity on the proliferation of cellular contents of seminiferous tubules elucidated the mechanism of dose-dependent drug induced testicular damage during 
spermatogenesis. MTX treatment showed autolytic changes in the center of tubules (meshy appearance) and less space between the spermatogonia cells. The spermatogonia cells were larger in some tubules and cytoplasm was darkly stained. The spermatogenesis was not complete in some tubules (Figure 1B). When MTX was given along with VA, VA minimized the severity of damage caused by MTX (Figure 1C).

\subsection{Expression of NORs in the testis (Table 1)}

\subsubsection{Total count of NORs}

There was an overall numerical decrease in the total NOR count from the control to $12 \mathrm{mg}$ dose MTX. The total count included small, medium and large sized NORs. A statistically significant difference was found from the control to $12 \mathrm{mg}$ dose MTX $(\mathrm{p}<0.05)$ as well as between the doses $(\mathrm{p}<0.05)$.

\subsubsection{Large sized NORs $>3 \mu m$}

Large sized NORs showed an increase in their number with MTX. However there was no significant difference between the control and other doses except with the $10 \mathrm{mg}$ dose MTX $(\mathrm{p}<0.05)$.

\subsubsection{Medium sized NORs $>1 \mu m$ to $3 \mu m$}

It showed a statistical difference $(\mathrm{p}<0.05)$ between control and MTX treated groups. There was high count in the medium sized NORs. The maximum numbers of medium sized NORs were in $8 \mathrm{mg}$ dose MTX.

\subsubsection{Small sized NORs $<1 \mu m$}

The data showed a decrease in the numerical count from the control to $8 \mathrm{mg}, 10 \mathrm{mg}$ dose and $12 \mathrm{mg}$ dose MTX. Lowest numerical count of NORs was found in the $10 \mathrm{mg}$ dose MTX. An overall statistical significant difference $(\mathrm{p}<0.05)$ was found.

\subsubsection{Regular shaped NORs}

Regular shaped NORs showed the lowest numerical count in $10 \mathrm{mg}$ dose MTX. The data showed a statistical significant difference within the group $(\mathrm{p}<0.05)$. However there was no statistical significant difference between the doses except between control and $10 \mathrm{mg}$ dose MTX.

\subsubsection{Irregular shaped NORs}

Irregular shaped NORs showed the lowest numerical count in control. The irregular shaped NORs increased in count with MTX $(\mathrm{p}<0.05)$. The data showed a statistical significant difference within the group. However there was no statistical significant difference between the doses except between control and $10 \mathrm{mg}$ dose MTX.

\subsubsection{VA effect}

When VA was given along with MTX, the NOR expression was reversed. The count was significantly increased in the $\mathrm{VA}+\mathrm{MTX}$ treated group when compared to $12 \mathrm{mg}$ dose of MTX treated group. The count was almost close to that of control group (Table 1).
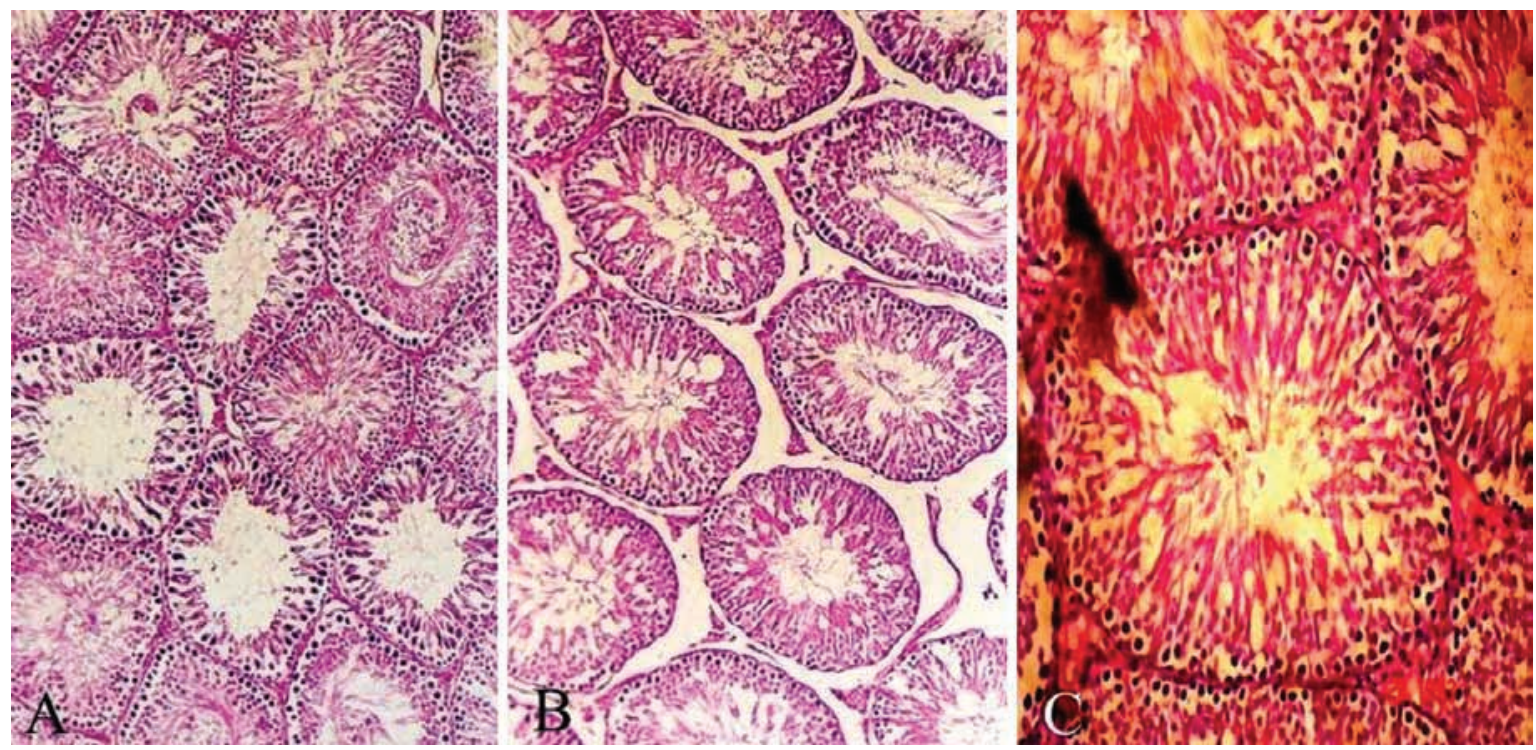

Figure 1. Showing the histopathology (eosin and haemotoxylin stain) of the testis (A- control rat; B- 12 mg methotrexate treated rat; $\mathrm{C}$ - vitamin $\mathrm{A}$ and $12 \mathrm{mg}$ methotrexate treated rat).

Table 1. Expression of NORs in MTX and VA treated rat's testis (mean \pm SD from 6 animals/group).

\begin{tabular}{lccrrrr}
\hline $\begin{array}{c}\text { Experimental } \\
\text { group }\end{array}$ & Total & Large & Medium & Small & \multicolumn{1}{c}{ Regular } & Irregular \\
\hline Control & $101.66 \pm 2.98$ & $20.5 \pm 2.81$ & $33.66 \pm 2.86$ & $46.66 \pm 3.54$ & $60.66 \pm 4.1$ & $39.33 \pm 4.1$ \\
8 mg MTX & $96.16 \pm 2.4$ & $22.33 \pm 2.42$ & $40.83 \pm 1.77$ & $37 \pm 2.58$ & $55.66 \pm 3.39$ & $44.33 \pm 3.39$ \\
$10 \mathrm{mg}$ MTX & $73.66 \pm 2.35$ & $26.5 \pm 2.06$ & $39 \pm 1.54$ & $34.5 \pm 1.89$ & $53.33 \pm 3.24$ & $46.66 \pm 3.24$ \\
$12 \mathrm{mg}$ MTX & $53.16 \pm 2.11$ & $23 \pm 1.63$ & $39.66 \pm 1.49$ & $37.33 \pm 1.59$ & $55.5 \pm 3.09$ & $44.5 \pm 3.09$ \\
VA & $101.83 \pm 2.79$ & $20.83 \pm 2.4$ & $34 \pm 2.08$ & $45.16 \pm 2.26$ & $61 \pm 2.16$ & $39 \pm 2.16$ \\
VA + MTX & $99.66 \pm 3.03$ & $20.66 \pm 1.88$ & $36.33 \pm 1.1$ & $43 \pm 1.73$ & $60.16 \pm 3.33$ & $39.83 \pm 3.33$ \\
\hline
\end{tabular}




\section{Discussion}

Animal studies are important because, in some situations, they shed light on mechanisms of teratogenecity and when such a drug causes similar patterns of anomalies in several species, human teratogenesis should be suspected (NATEKAR, 2007). In the present study, the plan was to evaluate the effect of agents such as MTX and VA on NOR expression of seminiferous tubules in Wistar rats. It was believed that the outcome of the study might be useful in better understanding the long term effects of MTX and also to overcome or minimize its adverse effects. MTX is an antimetabolite drug widely used in cancer chemotherapy; however, gastrointestinal toxicity is one of the serious side effects in the MTX treatment. The antimitotic effect of MTX is known to cause malabsorption syndrome. However, the mechanism of toxicity has not been completely clarified. Alterations to mucosal surfaces of the gastrointestinal tract and diarrhea are well-documented side effects of MTX in humans, attributable to MTX acting on the rapidly dividing mucosal cells (HOWELL, 1982; HUBBELL, ROTHBLUM and HSU, 1979). MTX injury is exacerbated by malnutrition and consumption of an elemental diet (MAMAEV, MAMAEVA, LIBURKINA et al., 1985), the cell cycle and proliferative activity in some circumstances (MAMAEV, MAMAEVA, LIBURKINA et al., 1985; DERENZINI, PESSION, FARABEGOLI et al., 1989; LEEK, SARRAF and ALISION, 1990; SURESH, CHAWNER, BUCKLEY et al., 1990; CROCKER, 1990), but alleviated by co-administration of VA (CAPOA, FERRARO, MENENDEZ et al., 1978; MILLER, DEV, TANTRAVAHI et al., 1978), suggesting that diet plays an important role in this mode of injury. Moreover, being a high affinity inhibitor of dihydrofolate reductase, MTX indirectly affects the synthesis of thymidylate, suppressing DNA synthesis (HUBBELL, ROTHBLUM and HSU, 1979). Additionally, it was demonstrated that the cytosolic NADPdependent dehydrogenases and NADP malic enzyme were inhibited by MTX, suggesting that the drug could decrease the availability of NADPH in the cells (WARBURTON and HENDERSON, 1979). Under normal conditions, NADPH is used by glutathione reductase to maintain the reduced state of cell glutathione, which is known as an important cytosolic antioxidant, protective against reactive oxygen species (ROS). Thus, the significant reduction in glutathione (GSH) levels promoted by MTX leads to a reduction of effectiveness of the antioxidant enzyme defense system, sensitizing the cells to ROS (BUFO, LOSACCO and LATORRE et al., 2000). MTX binds tightly to the dihydrofolate reductase. This enzyme is going to catalyse the NADPH-dependent reduction of dihydrofolate to tetrahydrofolate, which is utilized as a one carbon carrier. This is required for the synthesis of purine and pyrimidine, including thymidilate synthesis. This is essential for DNA synthesis and cell division (HUBBELL, ROTHBLUM and HSU, 1979). On the other hand, it has been suggested that VA may be involved in the regulation of DNA and RNA synthesis (YUNCU, ERALP, KORUK et al., 2004; SIDDIQUI, SOOMRO, KAYANI et al., 1999).

Cell cycle is the 'program' for cell growth and cell division. There are 4 broad phases of the cell cycle; Gl (and G0), S, G2 and M. The G1 (gapl) phase is characterized by gene expression and protein synthesis. This is really the only part of cell cycle regulated primarily by extra-cellular stimuli (like mitogens and adhesion). When MTX is given, a small proportion of the cells are observed to have passed into the G2 phase where synthesis of cellular components necessary for mitotic cell division takes place. The majority of them are blocked at the $S$ phase where replication of the DNA genome is observed to take place (DAGDEMIR, YILDIRIM, ALIYAZICIOGLU et al., 2004). This phase enables the cells to grow and produce all the necessary proteins for DNA synthesis. Cancer cells escape from the controls on cell division and the action mechanism of antineoplastic drug is based on the stopping of uncontrolled cells at any one stage of the cell cycle (DHAR, KUMAR, NAYAK et al., 1995). To further understand the relationship between the cell cycle and quantity of AgNOR proteins, it is necessary to determine the phases of cell cycle during which expression of $\mathrm{AgNOR}$ varies and it is important to know the most variable proteins in each phase (CROCKER, BOLDY and EGAN, 1989). The higher value indicates that the major parts of the cells are in the S-G2 phase and correlatively few are in the Gl phase and this characterizes a rapid cell cycle (CROCKER, BOLDY and EGAN, 1989). However in the present study, the count was decreased from the control to higher dose of MTX. This indicates that major parts of the cells are in the Gl phase and correlatively few cells are in the S-G2 phase.

NORs stained with colloidal silver techniques, evidence sites of active rRNA transcription. It has been proven that AgNOR undergo a rise in number and variations in size and shape in conditions, which traditionally involve enhanced cell proliferation and rRNA transcription. AgNOR have been described as a marker of malignant transformation in multiple entities (NATEKAR, 2007). AgNOR proteins are a set of argyrophilic nucleolar proteins that accumulate in highly proliferating cells whereas their expression is very low in non-proliferating cells. Some of these proteins remain associated with the NORs during mitosis. In situ, the expression of $\mathrm{AgNOR}$ proteins is measured globally by quantification of the level of silver staining using morphometry and image analysis.

In the present study, the total NORs irrespective of their shape and size followed a progressively decreasing pattern that correlated with the dose of MTX. An apparent decrease in the total NOR count found in the present study could be due to inactive cell proliferation because of the blockage in the $S$ phase of cell cycle, decrease in cell ploidy, resulting in a real decrease in AgNOR bearing chromosomes or decrease in the transcriptional activity. It has been generally found that quantity of silver stained NOR proteins, is strictly related to the cell proliferation (ZACHARIAE, 1980). VA has reversed the activity of MTX. The irregularity of NORs refers to aggregation of multiple NORs in a site, thus reflecting the greater transcriptional rate. In the present study, the total numbers of irregular dots were less in high dose of MTX than the control group and the total number of regular NORs were less in control than high dose MTX treated group. This indicates that transcriptional rate was less in high doses of MTX than the control group. Less transcriptional rate, reduced the total NOR count which in turn reduced the overlapping or aggregation of NORs in a single cell. 
When VA was given after the high dose of MTX, it reversed the activity of MTX.

MTX is known to cause a number of adverse effects. The most reported adverse effects include ulcerative stomatitis, leucopenia, nausea and abdominal distress. Severe heamatological gastrointestinal toxicity, intestinal pneumonitis, liver damage, renal failure, intellectual deficit and wide spectrum of neurotoxic reactions are also reported (KLABER, 1982). Other adverse effects are malaise, undue fatigue, chills and fever, dizziness and decreased resistance to infections. In the alimentary system, it shows gingivitis, pharyngitis, stomatitis, anorexia, nausea, vomiting, diarrhea, gastrointestinal tract ulceration and bleeding. Administration of VA decreases the MTX induced damage to the small intestine. This protective effect of VA may have clinical applications in cancer chemotherapy (DOROSHOW, LOCKER, GAASTERLAND et al., 1981). The administration of VA before high dose MTX may protect against drug induced D-xylose malabsorption in children with cancer (GONG and GLUUD, 2010). Some studies have shown that biochemical modulation used to prevent MTX induced malabsorption by VA co-administration will be of great use in MTX cancer cheamotherapy (CHLADEK, MARTINKOVA and SISPERA, 1997). The oral administration of MTX to rats, inhibit DNA synthesis in crypt cells. VA co-administration protects the salvage pathway of pyrimidine synthesis and denovo purine synthesis in crypt cells (MILLER, DEV, TANTRAVAHI et al., 1978). It has been shown histologically, biochemically and physiologically that VA protects the small intestine from the damage induced by MTX (CAPOA, FERRARO, MENENDEZ et al., 1978).

VA protects gastric mucosal damage produced by the MTX administration. In the present study, NOR frequency was reduced when treated with MTX. But when treated with MTX and VA, NOR frequency increased and reached almost the level of control group. Hence the present study confirms that VA minimizes the genotoxic and cytotoxic effects of MTX. These might have clinical reference for the prevention and minimization of diarrhea in MTX treatment (SHAFIK, 1993). Madhyastha, Bairy and Somayaji (2007) reported that, VA protects against the methotrexate induced genetic damage. It was also reported that, both vitamin A and leucovorin can protect against the genetic damage which is induced by methotrexate (MADHYASTHA, PRABHU, SARALAYA et al., 2008). In the other study (RAGHUNATHAN, BAIRY, BHAT et al., 2009), the authors found that MTX treatment showed disruption of normal hepatic plates, vacuolation of the hepatocytes, nuclear variability and enlarged blood vessels. In that study (RAGHUNATHAN, BAIRY, BHAT et al., 2009) also VA protected the damages produced by the MTX administration. We believe that NOR quantitation is a handy and potentially useful biomarker, in the cancer management. However, the limitation is its role in assessing the efficacy of antitumor therapy, as compared to that of histological examination, serological markers or imaging modalities, is less clear.

\section{Conclusion}

It is evident from the present study that MTX decreased the total count of AgNORs. A decrease in the AgNOR count was due to the inactive proliferation of cells (anti-proliferative activity of MTX). The inactive cell proliferation was because of the blockage in the ' $S$ ' phase of the cell cycle by MTX. MTX decreased the cell ploidy, resulting in a real decrease in AgNOR bearing chromosome. Here, MTX reduced the transcriptional activity of the cells. That was another reason for the reduction of AgNOR count. The irregularity of NORs refers to the aggregation of more than one NOR in a site, thus reflecting greater transcriptional rate. However, MTX reduced the transcriptional activity and hence the decreased AgNOR count in high dose group compared to the control group.

Higher the dose of MTX, lesser the NOR count and lesser the irregularity of NORs. However VA co-administration reduces the damage produced by MTX. Therefore, our findings may be useful in better understanding of the longterm effect of MTX and also to overcome or minimize its adverse effects.

Acknowledgements: The authors thank all the non-teaching members of the department of anatomy for their valuable help in conducting this study.

\section{References}

BUFO, P., LOSACCO, T., LATORRE, V., PARISI, G. and SANTACROCE, L. Assessment of hepatocyte AgNORs expression in chronic hepatopathy. La Clinica Terapentica, 2000, vol. 151, n. 6, p. 417-419. PMid:11211475.

CHLADEK, J., MARTINKOVA, J. and SISPERA, L. An in vitro study on methotrexate hydroxylation in rat and human liver. Physiological Research, 1997, vol. 46, n. 5, p. 371-379. PMid:9728483.

CROCKER, J. Nucleolar organiser regions. Current Topics in Pathology, 1990, vol. 82, p. 91-149. PMid:2186898. http://dx.doi. org/10.1007/978-3-642-74668-0_3

CROCKER, J., BOLDY, DA. and EGAN, MJ. How should we count AgNORS? Proposals for a standardized approach. The Journal of Pathology, 1989, vol. 158, n. 3, p. 185-188. PMid:2475599. http://dx.doi.org/10.1002/path.1711580303

DAGDEMIR, A., YILDIRIM, H., ALIYAZICIOGLU, Y., KANBER, Y., ALBAYRAK, D. and ACAR, S. Does vitamin A prevent high-dose-methotrexate-induced D-xylose malabsorption in children with cancer? Supportive Care in Cancer, 2004, vol. 12, n. 4, p. 263-267. PMid:14767751. http://dx.doi.org/10.1007/ s00520-004-0591-8

CAPOA, A., FERraro, M., MENENDEZ, F., MOSTACCI, C., PELLICCIA, F. and ROCCHI, A. Ag staining of the nucleolus organizer $(\mathrm{NO})$ and its relationship to satellite association. Human Genetics, 1978, vol. 44, n. 1, p. 71-77. PMid:81799. http://dx.doi. org/10.1007/BF00283576

DERENZINI, M., PESSION, A., FARABEGOLI, F., TRERE, D., BADIALI, M. and DEHAN, P. Relationship between interphasic nucleolar organizer regions and growth rate in two neuroblastoma cell lines. The American Journal of Pathology, 1989, vol. 134, n. 4, p. 925-932. PMid:2705511 PMCid:PMC1879788.

DHAR, PK., KUMAR, MR., NAYAK, S., RAO, TR., JOSEPH, A., DEVI, S., KUAMARI, U., BHAT, SM. and BHAT, KR. A rapid silver staining and destaining technique for the nucleolus organizer region. Biotechnic and Histochemistry, 1995, vol. 70, n. 6, p. 302-303. PMid:9044659. http://dx.doi. org/10.3109/10520299509108337 
DOROSHOW, JH., LOCKER, GY., GAASTERLAND, DE., HUBBARD, SP., YOUNG, RC. and MYERS, CE. Ocular irritation from high dose methotrexate therapy: pharmacokinetics of drugs in the tear film. Cancer, 1981, vol. 48, n. 10, p. 2158-2162. http:// dx.doi.org/10.1002/1097-0142(19811115)48:10<2158::AIDCNCR2820481007>3.0.CO;2-I

EL-BEHEIRY, A., EL-MANSY, E., KAMEL, N. and SALAMA, N. Methotrexate and fertility in men. Systems Biology in Reproductive Medicine, 1979, vol. 3, n. 2, p. 177-179. http://dx.doi. org/10.3109/01485017908985067

FAKAN, S. and HERNANDEZ-VERDUN, D. The nucleolus and the nucleolar organizer regions. Biology of the Cell, 1986, vol. 56, n. 3, p. 189-205. PMid:2943350. http://dx.doi.org/10.1111/ j.1768-322X.1986.tb00452.x

FAWCETT, DW. A text book of histology. 12th ed. New York: Chapman and Hall, 1994. p. 1-56.

GONG, Y. and GLUUD, C. Methotrexate for primary biliary cirrhosis. Cochrane Database of Systematic Reviews, 2010, vol. 12, n. 5, CD004385.

HOWELL, WM. Selective staining of nucleolar organizing regions (NORs). In BUSCH, H. and ROTHBLUM, L. (Eds). The cell nucleus. New York: Academic Press, 1982. p. 89-143.

HUBBELL, HR., ROTHBLUM, LI. and HSU, TC. Identification of a silver binding protein associated with the cytological silver staining of actively transcribing nucleolar regions. Cell Biology International Reports, 1979, vol. 3, n. 7, p. 615-622. http:// dx.doi.org/10.1016/0309-1651(79)90060-2

KLABER, MR. Prospective study of liver biopsies in patients with psoriasis receiving methotrexate therapy. British Journal of Dermatology, 1982, vol. 107, p. 48.

LEEK, RA., SARRAF, CE. and ALISION, MR. The relationship of AgNOR size and number to proliferative status in a range of renewing and neoplastic tissue. The Journal of Pathology, 1990, vol. 161, n. 3, p. 342-362.

MADHYASTHA, S., BAIRY, KL. and SOMAYAJI, SN. Protective effect of vitamin A on methotrexate induced micronuclei. Iranian Journal of Pharmacology \& Therapeutics, 2007, vol. 6, n. 1, p. 1-4.

MADHYASTHA, S., PRABHU, LV., SARALAYA, V. and RAI, R. A comparison of vitamin A and leucovorin for the prevention of methotrexate-induced micronuclei production in rat bone marrow. Clinics, 2008, vol. 63, n. 6, p. 821-826. PMid:19061007 PMCid:PMC2664285. http://dx.doi.org/10.1590/S180759322008000600019

MAMAEV, N., MAMAEVA, S., LIBURKINA, I., KOZLOVA, T., MEDVEDEVA, N. and MAKARKINA, G. The activity of nucleolar organizer regions of human bone marrow cells studied with silver staining. I. Chronic myelocytic leukemia. Cancer Genetics and Cytogenetics, 1985, vol. 16, n. 4, p. 311-320. http://dx.doi. org/10.1016/0165-4608(85)90239-0
MILlER, DA., DEV, VG., TANTRAVAHI, R., CROCE, CM. and MILLER, OJ. Human tumor and rodent-human hybrid cells with an increased number of active human NORs. Cytogenetic and Genome Research, 1978, vol. 21, n. 1-2, p. 33-41. http://dx.doi. org/10.1159/000130876

NATEKAR, PE. Methotrexate induced gross malformations in chick embryos. The Journal of Human Ecology, 2007, vol. 21, n. 3, p. 223-226.

PLOTON, D., MENAGER, M., JEANNESSON, P., HIMBER, G., PIGEON, F. and ADNET, JJ. Improvement in the staining and in the visualization of the argyrophilic proteins of the nucleolar organizer region at the optical level. The Histochemical Journal, 1986, vol. 18, n. 1, p. 5-14. PMid:2423479. http://dx.doi. org/10.1007/BF01676192

RAGHUNATHAN, D., BAIRY, KL. and BHAT, KR. Effect of methotrexate on AgNOR count in liver of Wistar rats. Iranian Journal of Pharmacology \& Therapeutics, 2009, vol. 8, n. 1, p. 1115.

SHAFIK, A. Intratunical injection of methotrexate for the treatment of seminoma of the testicle. Anticancer Drugs, 1993, vol. 4, n. 2, p. 193-195. PMid:8490198. http://dx.doi. org/10.1097/00001813-199304000-00010

SIDDIQUI, MS., SOOMRO, IN., KAYANI, N., MUZAFFAR, S. and HASAN, SH. Assessment of nucleolar organizer regions (NORs) in proliferative conditions of the liver. Pathology - Research and Practice, 1999, vol. 195, n. 6, p. 421-426. http://dx.doi. org/10.1016/S0344-0338(99)80016-8

SURESH, UR., CHAWNER, L., BUCKLEY, CH. and FOX, H. Do AgNOR counts reflect cellular ploidy or cellular proliferation? A study of trophoblastic tissue. The Journal of Pathology, 1990, vol. 160, n. 3, p. 213-215. PMid:2335802. http://dx.doi. org/10.1002/path.1711600306

WARBURTON, D. and HENDERSON, AS. Sequential silver staining and hybridization in situ on nucleolus organizing regions in human cells. Cytogenetic and Genome Research, 1979, vol. 24, n. 3, p. 168-175. http://dx.doi.org/10.1159/000131373

YUNCU, M., ERALP, A., KORUK, M., SARI, I., BAGCI, C. and INALOZ, S. Effect of vitamin A against methotrexate-induced damage to the small intestine in rats. Medical Principles and Practice, 2004, vol. 13, n. 6, p. 346-352. PMid:15467310. http://dx.doi. org/10.1159/000080472

ZACHARIAE, H. Methotrexate induced liver cirrhosis. British Journal of Dermatology, 1980, vol. 102, n. 4, p. 407-412. PMid:7387883. http://dx.doi.org/10.1111/j.1365-2133.1980. tb06553.x 